\title{
Effect of water addition and the urease inhibitor NBPT on the abatement of ammonia emission from surface applied urea
}

\author{
Alberto Sanz-Cobena ${ }^{\mathrm{a}, *}$, Thomas Misselbrook ${ }^{\mathrm{b}}$, Vicci Camp ${ }^{\mathrm{b}}$, Antonio Vallejo ${ }^{\mathrm{a}}$ \\ ${ }^{a}$ ETSI Agrónomos, Technical University of Madrid, Ciudad Universitaria, 28040 Madrid, Spain \\ ${ }^{\mathrm{b}}$ North Wyke Research, North Wyke, Okehampton, Devon EX20 2SB, UK
}

\section{A R T I C L E I N F O}

\section{Article history:}

Received 19 May 2010

Received in revised form

15 December 2010

Accepted 21 December 2010

\section{Keywords:}

Urea

Ammonia

Urease inhibitors

Wind tunnels

Rainfall

\begin{abstract}
A B S T R A C T
Urea is considered the cheapest and most commonly used form of inorganic $\mathrm{N}$ fertiliser worldwide. However, it has been estimated that $5-30 \%$ of the urea $\mathrm{N}$ is lost as volatilised $\mathrm{NH}_{3}$. Implementation of $\mathrm{NH}_{3}$ mitigation strategies is crucial in order to reduce both the economic and environmental impact associated with $\mathrm{NH}_{3}$ losses from urea application. Urease activity inhibitors and water addition to the soil have been proposed by UNECE (i.e. Gothenburg Protocol) as means to reduce $\mathrm{NH}_{3}$ emission from fertiliser applications. In this study, two field experiments were carried out in order to test the effectiveness of water addition as $\mathrm{NH}_{3}$ mitigation technique from surface applied urea in comparison with the use of the urease inhibitor NBPT. A system of wind tunnels was used to measure $\mathrm{NH}_{3}$ fluxes. Contrasting irrigation strategies (or rainfall patterns), in terms of both rate and timing, were used in order to evaluate the amount of water necessary to achieve a significant $\mathrm{NH}_{3}$ mitigation. The addition of 7 and $14 \mathrm{~mm}$ of water to the soil, immediately after urea spreading, reduced $\mathrm{NH}_{3}$ emission by 77 and $89 \%$, respectively, similar to that achieved using NBPT (77-88\% reduction). In contrast, a simulated $3 \mathrm{~mm}$ rainfall, immediately after fertilising, significantly enhanced $\mathrm{NH}_{3}$ volatilisation (with an $8 \%$ increase in emission compared to urea application without water addition). These results demonstrate the potential of correct water management in abating $\mathrm{NH}_{3}$ volatilisation from urea applications to soil, giving a similar effect to that of the urease inhibitor NBPT under the experimental conditions presented here.
\end{abstract}

(C) 2010 Elsevier Ltd. All rights reserved.

\section{Introduction}

Since the invention of the Haber-Bosch process in 1908, through which ammonia $\left(\mathrm{NH}_{3}\right)$ can be synthesised from atmospheric nitrogen $\left(\mathrm{N}_{2}\right)$, the use of synthetic $\mathrm{N}$ fertilisers has become common in many parts of the world (Erisman et al., 2007). Among the different forms of synthetic $\mathrm{N}$ fertilisers applied nowadays, urea is considered the cheapest and most commonly used form of inorganic $\mathrm{N}$ fertiliser (Thompson and Meisinger, 2004), accounting for c. $50 \%$ of total inorganic $\mathrm{N}$ use. However, it has been estimated that between 5 and $30 \%$ of the urea $\mathrm{N}$ is lost as volatilised $\mathrm{NH}_{3}$ (UNECE, 2001; Erisman et al., 2007). Bouwman et al. (1997) estimated that, from the $78 \times 10^{9} \mathrm{~kg}$ of inorganic $\mathrm{N}$ applied globally (1995), $14 \%$ is lost as $\mathrm{NH}_{3}$, with $65 \%$ of that amount lost from urea application. In a direct way, these losses of $\mathrm{NH}_{3}$ are responsible for an important decrease in the nutrient value of the applied urea (Van der Stelt et al., 2005). In addition, emissions of $\mathrm{NH}_{3}$ to the

\footnotetext{
* Corresponding author.

E-mail address: a.sanzcobena.agronomos@upm.es (A. Sanz-Cobena).
}

atmosphere can contribute to particulate matter formation affecting human health and to eutrophication and acidification of aquatic and terrestrial ecosystems after deposition (Erisman et al., 2007).

Since most of the $\mathrm{NH}_{3}$ emission from the use of synthetic fertilisers comes from urea, it represents a priority area for the development of potential mitigation techniques. According to the advisory code of good agricultural practices by the Expert Group on Ammonia Abatement (UNECE, 2001), mitigation of $\mathrm{NH}_{3}$ emissions from urea application can be achieved by a) specific measures based on incorporating it into the soil, b) applying it during appropriate weather conditions and c) the use of urease inhibitors (UNECE, 2001). The first two options are mainly focussed on enhancing the contact between ammonium $\left(\mathrm{NH}_{4}^{+}\right)$and the soil colloid in such a way that $\mathrm{NH}_{3}$ would be decreased in the soil solution. Addition of water to the soil surface, through rainfall or irrigation, immediately after surface application of urea would be included in this group. The third option, based on the use of urease activity inhibitors, is a biochemical method which retards the hydrolysis of urea by inhibiting the urease enzyme in the soil (Gill et al., 1997). Slowing urea hydrolysis allows more time for urea to 
diffuse into the soil following application. Therefore, the concentration of $\mathrm{NH}_{3}$ and $\mathrm{NH}_{4}^{+}$present in the soil solution near the surface is reduced, thus reducing the potential for volatilisation losses (Grant et al., 1996). Among the various types of urease inhibitors which have been identified and tested, $\mathrm{N}$-(n-butyl) thiophosphoric triamide (NBPT) has been found significantly effective at relatively low concentrations under both laboratory (Carmona et al., 1990; Gill et al., 1997) and field conditions (Sanz-Cobena et al., 2008; Zaman et al., 2009). Under field conditions, the inhibitor is normally applied by including it in granules of urea, which may limit the proportion of microsites where the enzyme is inhibited. It forms stable complexes with urease and is among the most efficient inhibitors of this enzyme after the conversion to its oxidised form (NBPTO) in soil (McCarty et al., 1989; Manunza et al., 1999). As urease is an enzyme present in a wide variety of fungi and bacteria species of soil, the efficiency of NBPT to decrease urease activity may depend on its diffusion from the application point and the concentration of inhibitor maintained in microsites. Although there is little information about the effect of rainfall or irrigation on the efficiency of urease inhibitors, we hypothesised that water application (i.e. irrigation or rainfall), following fertilisation, could enhance the effect of NBPT in mitigating $\mathrm{NH}_{3}$ emission. Alternatively, water application alone may prove an effective alternative mitigation technique and particularly appropriate where irrigation is routinely practised. However, there is limited information evaluating the effect of irrigation management on ammonia emission after urea application under field conditions, and in particular the effect of rate or frequency. The present study was conducted, therefore, to assess (1) the mitigation effect of the urease inhibitor NBPT with or without irrigation (or rainfall) on $\mathrm{NH}_{3}$ emission and (2) the effect of different rainfall (or irrigation) patterns on $\mathrm{NH}_{3}$ volatilisation after urea application.

\section{Materials and methods}

\subsection{Experimental site}

The experiment was conducted at North Wyke Research station in Devon, UK, on a clay loam soil (20\% sand, $50 \%$ silt, $30 \%$ clay) of the Hallsworth (Stagnogley; USDA Haplaquept) series with a $\mathrm{pH}$ in water of 5.3, bulk density $0.99 \mathrm{~g} \mathrm{~cm}^{-3}$ and $3.7 \%$ of organic carbon (Findlay et al., 1984). Average annual rainfall at North Wyke is $1035 \mathrm{~mm}$ and average soil temperature $(10 \mathrm{~cm}) 6{ }^{\circ} \mathrm{C}(\mathrm{min})$ and $13^{\circ} \mathrm{C}(\max )$.

\subsection{Experimental design}

Two experiments were conducted on a tilled area which had not previously been used by animals at North Wyke. The experimental area was selected and tilled on the 15th April 2008. Eighteen $2 \mathrm{~m}^{2}$ plots were used for each experiment. The first experiment was conducted between the 21st April and the 6th May 2008 and the second one between the 12th May and the 27th May 2008, in an adjacent area to that of experiment 1 and without any management practice in the meantime. Initial soil conditions at the start of experiments were WFPS of $61.6 \%$ and $39.1 \%$ and soil $\mathrm{NH}_{4}^{+}$soil content of 2.1 and $2.5 \mathrm{mg} \mathrm{NH}_{4}^{+}-\mathrm{N} \mathrm{kg}^{-1}$, for experiments 1 and 2, respectively, and bulk density of $0.99 \mathrm{~g} \mathrm{~cm}^{-3}$ for the two experiments.

Both experiments included 6 different treatments with 3 replications. Nine plots were fertilised with urea, used in granular form, and 9 with urea combined with the urease inhibitor NBPT (i.e. $\mathrm{U}+\mathrm{NBPT}$ ); both applied by hand at a rate of $100 \mathrm{~kg} \mathrm{~N} \mathrm{ha}^{-1}$. Urea was coated with the urease inhibitor NBPT shortly prior to application (as there was concern that the coated product may not be stable over the long-term), to give a proportion of inhibitor in the mixture of $0.14 \%$ on a weight basis. In each experiment, two different rainfall patterns (i.e. rate and frequency) were simulated in order to test their effect on incorporating the fertiliser into the soil and, therefore, reducing $\mathrm{NH}_{3}$ losses through volatilisation. In the first experiment, rainfall pattern 1 consisted in irrigating plots with $7 \mathrm{~mm}$ of water immediately after applications (treatments $U+7 ; U+N B P T+7$ ) using a watering can. Rainfall pattern 2 was based on irrigating with $7 \mathrm{~mm}$ of water immediately following application and then with a further $7 \mathrm{~mm}$ one week later (treatments $U+7+7$; $U+N B P T+7+7$ ). Plots without water application were also included as control (treatments $U$ and $\mathrm{U}+\mathrm{NBPT}$ ). Therefore, there were 6 different treatments (i.e. U; $\mathrm{U}+\mathrm{NBPT} ; \mathrm{U}+7 ; \mathrm{U}+\mathrm{NBPT}+7 ; \mathrm{U}+7+7 ; \mathrm{U}+\mathrm{NBPT}+7+7)$ with 3 replicates per treatment in a randomised block design.

The second experiment included two further rainfall patterns: applying $14 \mathrm{~mm}$ just after fertilising (treatments $\mathrm{U}+14$ and $\mathrm{U}+\mathrm{NBPT}+14)$, and $3 \mathrm{~mm}$ added immediately after application and followed by further $3 \mathrm{~mm}$ one week later (i.e. $U+3+3$ and $\mathrm{U}+\mathrm{NBPT}+3+3)$. Again, plots without rainfall were used as control (treatments $U$ and $U+$ NBPT) as well as for evaluating the effect of different temporal conditions on the results of the two experiments. Therefore, experiment 2 included the following treatments: $U$; $\mathrm{U}+\mathrm{NBPT} ; \mathrm{U}+14 ; \mathrm{U}+\mathrm{NBPT}+14 ; \mathrm{U}+3+3 ; \mathrm{U}+\mathrm{NBPT}+3+3$, with 3 replicates per treatment in a randomised block design.

Air and soil temperature $(2 \mathrm{~m}$ height and $10 \mathrm{~cm}$ depth, respectively) and relative humidity were monitored by a meteorological station located at the field site using temperature probes. Following Sommer and Olesen (1991), it was assumed that the wind tunnel canopy had no significant influence on temperature at the emitting surface.

\section{3. $\mathrm{NH}_{3}$ emission measurement}

A system of small wind tunnels, as described by Lockyer (1984) and evaluated by Van der Weerden et al. (1996) was used to measure $\mathrm{NH}_{3}$ emissions from surface applied urea. This technique is commonly used to measure $\mathrm{NH}_{3}$ emission from small experimental plots (e.g. $1 \mathrm{~m}^{2}$ ) for comparative purposes (Loubet et al., 1999a; Génermont et al., 1998; Misselbrook et al., 2005a). Each tunnel comprised a transparent polycarbonate canopy measuring $2 \times 0.5 \mathrm{~m}$, coupled to a steel duct which housed an electrically driven fan and an anemometer so that air flow through the tunnel could be controlled (at $1 \mathrm{~m} \mathrm{~s}^{-1}$ in the present study).

Ammonia concentration in the air entering and leaving the tunnel was measured by drawing air at $41 \mathrm{~min}^{-1}$ through absorption flasks containing $0.02 \mathrm{M}$ solution of orthophosphoric acid. Absorption flasks consisted of conical flasks containing between 80 and $100 \mathrm{ml}$ of acid solution, with air being drawn through the solution via an unscintered, open-ended glass rod (Misselbrook et al., 2005b). When the absorption flasks were returned to the laboratory the contents were made up to $100 \mathrm{ml}$ with deionised water. Each sample was then stored in a $30 \mathrm{ml}$ polystyrene vial in a cool room $\left(<4{ }^{\circ} \mathrm{C}\right)$ until they were analysed for ammonium- $\mathrm{N}$ concentrations by automated colorimetry (Searle, 1984), with $\mathrm{NH}_{4}^{+}$detection limits of 0.10 and $1.08 \mathrm{mg} \mathrm{N}^{-1}$ using the low $\left(0-5 \mathrm{mg} \mathrm{l}^{-1}\right.$-water) and high ranges (0-50 $\mathrm{mg} \mathrm{l}^{-1}$-water), respectively. The loss of ammonia from beneath each tunnel for each measurement period was calculated as the product of air which flowed through the tunnel and the difference between the concentrations of $\mathrm{NH}_{3}$ in the air entering and leaving the tunnel. Measurements continued for a period of $21 \mathrm{~d}$, with absorption flasks being changed every $24 \mathrm{~h}$.

Loss estimates in periods not measured (e.g. when absorption flasks were being changed) were made by averaging the rate of loss of the periods immediately before and immediately after the missing period and multiplying by the time. Tunnel canopies were placed covering the plot immediately following application of treatments and removed and then replaced again after irrigation. 


\subsection{Soil measurements}

Soil cores (0-10 cm depth) were collected several times during the two experiments in order to analyse the evolution of soil $\mathrm{NO}_{3}^{-}$, exchangeable $\mathrm{NH}_{4}^{+}$, urease activity and soil moisture. Mineral $\mathrm{N}$ content $\left(\mathrm{NO}_{3}^{-}-\mathrm{N}\right.$ and $\left.\mathrm{NH}_{4}^{-}-\mathrm{N}\right)$ was determined by extraction of $4 \mathrm{~g}$ of fresh soil with $50 \mathrm{ml} 2 \mathrm{M} \mathrm{KCl}$ followed by automated colorimetry (Searle, 1984). Urease activity was determined following the method of Nannipieri et al. (1980), involving the incubation of soil with buffered urea solution, the extraction of $\mathrm{NH}_{4}^{+}$with $1 \mathrm{~N} \mathrm{KCl}$ and colorimetric $\mathrm{NH}_{4}^{+}$determination. Urease activity of the experimental soil prior to fertilising was also determined.

Gravimetric soil moisture content was determined by drying samples to constant weight at $80^{\circ} \mathrm{C}$. Water-filled pore space (WFPS) was estimated by dividing the volumetric water content by total soil porosity. Total soil porosity was calculated by measuring the bulk density of the soil according to the relationship: soil porosity $=1-($ soil bulk density/2.65), assuming a particle density of $2.65 \mathrm{Mg} \mathrm{m}^{-3}$ (Danielson and Sutherland, 1986).

\subsection{Statistical analysis}

Statistical analysis was performed using Statgraphics Plus 5.1 (Manugistics, 2000). The data distribution normality of the $\mathrm{NH}_{3}$ fluxes and that of soil $\mathrm{NO}_{3}^{-}, \mathrm{NH}_{4}^{+}$was verified using the
Kolmogorov-Smirnov test. Differences between treatments were analysed using analysis of variance (ANOVA, $P<0.05$ ). The least significant difference (LSD) test was used for multiple comparisons between means. For non-normally distributed data, the Kruskal-Wallis test was used on non-transformed data to evaluate differences at $P<0.05$. Linear regression analyses $(P<0.05)$ were performed to determine relationships between $\mathrm{NH}_{3}-\mathrm{N}$ fluxes with soil $\mathrm{NH}_{4}^{-}-\mathrm{N}, \mathrm{NO}_{3}^{-}-\mathrm{N}$ and urease activity.

\section{Results}

\subsection{Experiment 1}

\subsubsection{Environmental conditions}

Initial WFPS was higher than $60 \%$, mainly due to precipitation on 21st and 22nd of April, which also enhanced the relative humidity of air (i.e. $\geq 80 \%$ ). Soil moisture was affected by irrigation, increasing to 69\% WFPS for the $7 \mathrm{~mm}$ irrigated soil for the 1 st day and decreasing progressively to $47.7 \%$ a week after. The second $7 \mathrm{~mm}$ of water added enhanced soil moisture content in $\mathrm{U}+7+7$ and $\mathrm{U}+\mathrm{NBPT}+7+7$ from 49.3 and $46.7 \%$ to 49.9 and $55.3 \%$, respectively. In soils without any water addition, WFPS decreased from 66 to $49 \%$ and 65 to $41 \%$ over the measurement period for $U$ and $\mathrm{U}+\mathrm{NBPT}$, respectively. Soil temperature (i.e. $10 \mathrm{~cm}$ depth) ranged between 9 and $12.5^{\circ} \mathrm{C}$ over the experimental period.
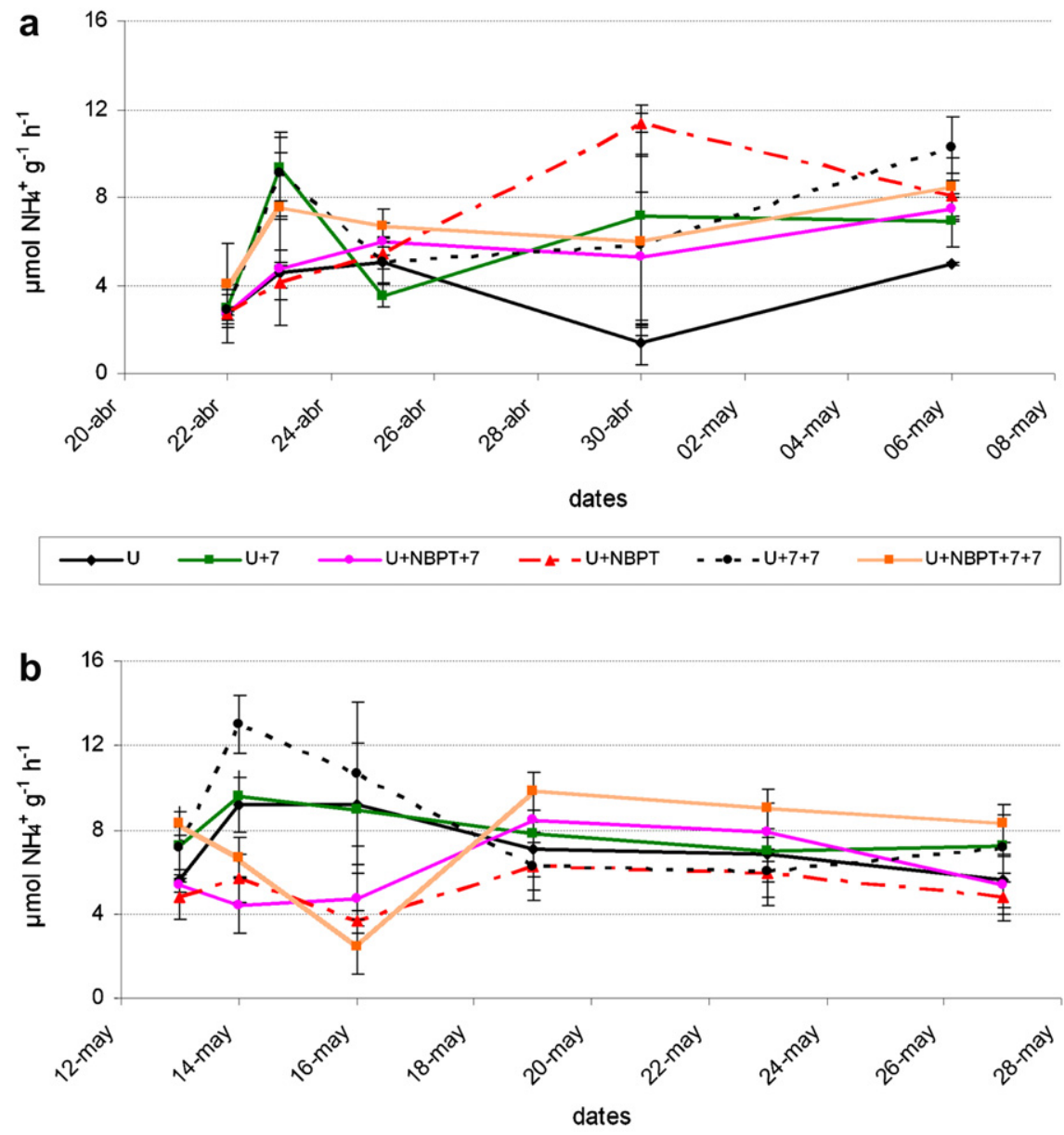

$\longrightarrow U \quad-U+14 \quad \longrightarrow U+N B P T+14 \quad-\leftarrow-U+N B P T \quad-\rightarrow-U+3+3 \quad \longrightarrow U+N B P T+3+3$

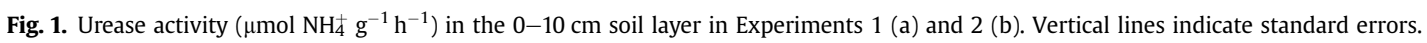




\subsubsection{Evolution of mineral $N$ and urease activity}

Urease activity of all treated plots was similar immediately after fertiliser application. After $24 \mathrm{~h}$, urease activity was lower in the NBPT treated plots than in those where the urea was applied without the inhibitor (Fig. 1a), with rates up to $8 \mu \mathrm{mol} \mathrm{NH}_{4}^{+} \mathrm{g}^{-1} \mathrm{~h}^{-1}$ in the latter case. After 3 days, there was no significant difference in urease activity between treatments.

In those plots irrigated immediately after fertilising, urease activity remained constant (at c. $6 \mu \mathrm{mol} \mathrm{NH}_{4}^{+} \mathrm{g}^{-1} \mathrm{~h}^{-1}$ ) for the duration of the experimental period. There was no effect of the 2 nd simulated rainfall (i.e. $7 \mathrm{~mm}$ ) on urease activity (Fig. 1a).

Exchangeable ammonium ( $\mathrm{NH}_{4}^{+}$) was affected by the presence of NBPT. Soil ammonium concentration $(0-10 \mathrm{~cm})$ was significantly higher for $U$ soil than for other treatments immediately after fertilising, whereas no significant differences were observed in the exchangeable $\mathrm{NH}_{4}^{+}$between the other treatments. A progressive decrease in the pool of $\mathrm{NH}_{4}^{+}$was observed in all treatments except U+NBPT, without any irrigation, where increasing concentrations were measured (Fig. 2a). No significant differences in $\mathrm{NO}_{3}^{-}$concentrations between the differently treated plots were measured within the experiment. Soil $\mathrm{NO}_{3}^{-}$ concentration increased over the experimental period in all treatments, with a peak value of $20.7 \mathrm{mg} \mathrm{NO}-\mathrm{N} \mathrm{kg}^{-1}$ measured in the $\mathrm{U}+7$ soil. At the end of the experimental period, the treatments with the lowest $\mathrm{NO}_{3}^{-}$concentration were $\mathrm{U}+\mathrm{NBPT}$ and $U$ (Fig. 3a).

\subsubsection{Ammonia emission}

Ammonia emission from $U$ started to increase immediately after fertilising, peaking $48 \mathrm{~h}$ after application and declining to background levels after $7 \mathrm{~d}$ (Fig. 4a). No significant differences were found in $\mathrm{NH}_{3}$ emission rate between $\mathrm{U}+7$ and $\mathrm{U}+7+7$ throughout the experimental period (Fig. 4a). Generally, the addition of water (i.e. $7 \mathrm{~mm}$ ) resulted in an earlier peak in $\mathrm{NH}_{3}$ emission (after $24 \mathrm{~h}$ ), with the exception of $\mathrm{U}+\mathrm{NBPT}+7$, where $\mathrm{NH}_{3}$ emissions were lower than $0.5 \mathrm{~kg} \mathrm{~N}-\mathrm{NH}_{3}$ ha ${ }^{-1} \mathrm{~d}^{-1}$ throughout the experiment.

Inclusion of NBPT with urea fertiliser, with no irrigation, significantly reduced the peak emission rate at $48 \mathrm{~h}(\mathrm{U}+$ NBPT vs. U, Fig. 4a). With $7 \mathrm{~mm}$ irrigation, the effect of NBPT was less clear, as $\mathrm{U}+\mathrm{NBPT}+7$ had the lowest emission rates, but $\mathrm{U}+\mathrm{NBPT}+7+7$ had a higher initial emission rate (after $24 \mathrm{~h}$ ) than either $U+7$ or $\mathrm{U}+7+7$ (Fig. 4a).

Highest cumulative $\mathrm{NH}_{3}$ emission over $12 \mathrm{~d}$ was from $\mathrm{U}$ (31.4 $\pm 5.8 \mathrm{~kg} \mathrm{~N} \mathrm{ha}^{-1}, 31 \%$ of N applied), followed by U $+\mathrm{NBPT}+7+7$ $\left(11.9 \pm 0.9 \mathrm{~kg} \mathrm{~N} \mathrm{ha}^{-1}\right)$. The treatment producing the lowest emissions was $\mathrm{U}+\mathrm{NBPT}+7\left(3.2 \pm 0.7 \mathrm{~kg} \mathrm{Nha}^{-1}\right)$. No significant differences were found between the other treatments (Table 1 ).

\subsection{Experiment 2}

\subsubsection{Environmental conditions}

Initial soil moisture was lower than in the previous experiment. Immediately after placing the tunnel canopies, WFPS ranged
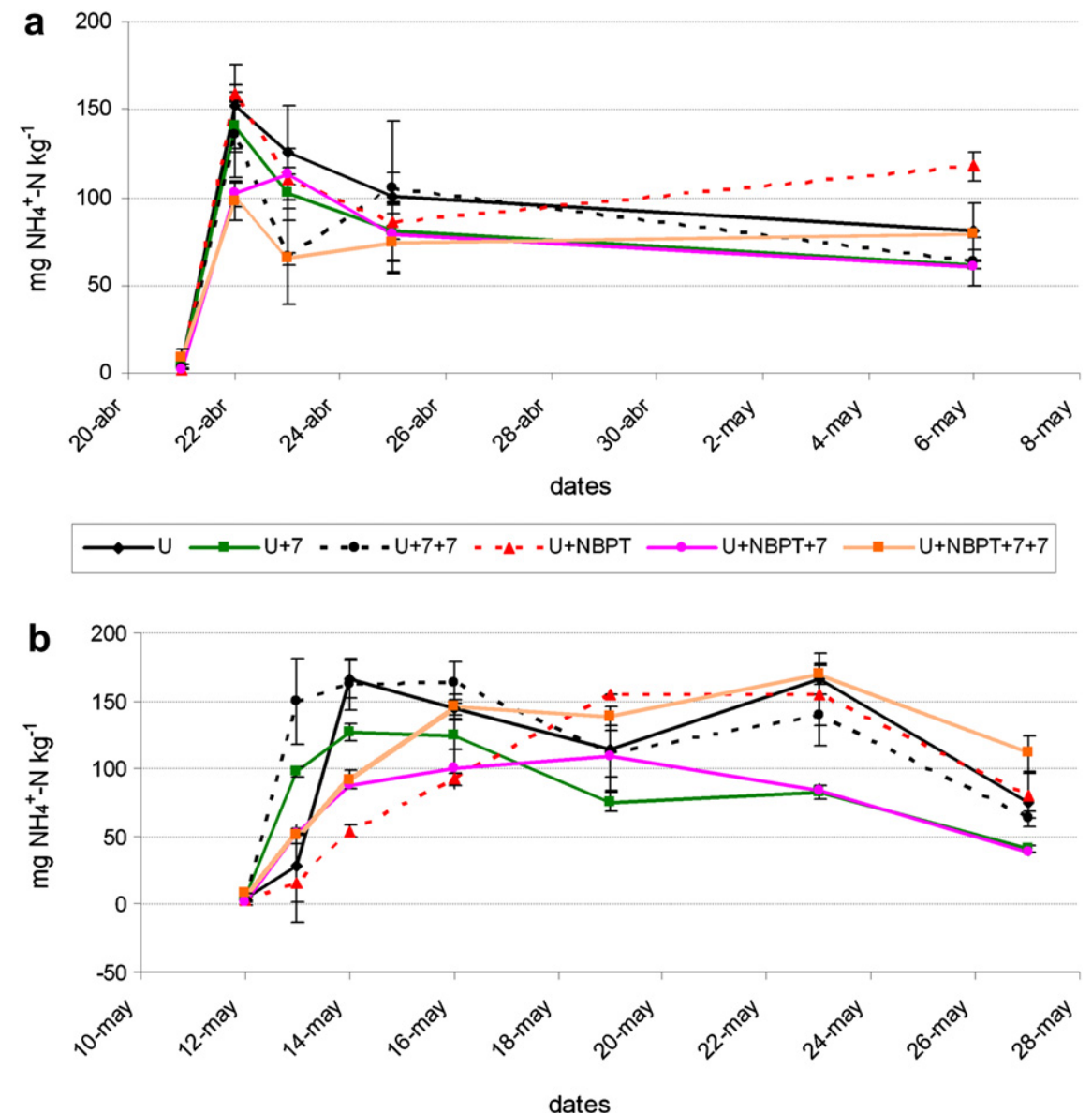

$\longrightarrow U \longrightarrow U+14-\bullet--U+3+3--\Delta--U+N B P T \longrightarrow U+N B P T+14 \longrightarrow U+N B P T+3+3$

Fig. 2. $\mathrm{NH}_{4}^{+}-\mathrm{N}$ concentrations ( $\mathrm{mg} \mathrm{NH}_{4}^{+}-\mathrm{N} \mathrm{kg}^{-1}$ ) in the $0-10 \mathrm{~cm}$ soil layer during the Experiment 1 (a) and 2 (b), respectively. Vertical lines indicate standard errors. 

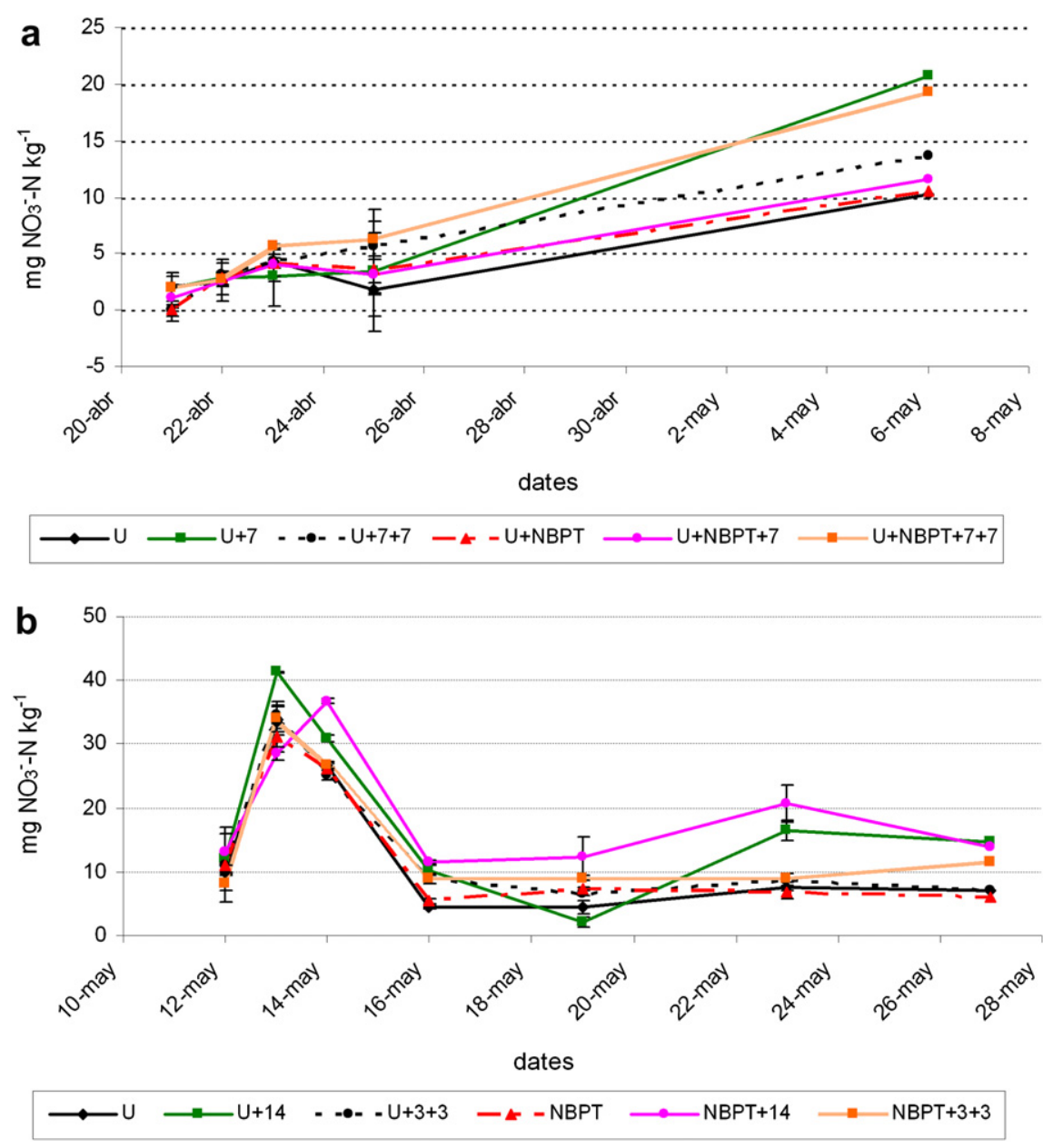

Fig. 3. $\mathrm{NO}^{-}-\mathrm{N}$ concentrations $\left(\mathrm{mg} \mathrm{NO}_{3}^{-}-\mathrm{N} \mathrm{kg}^{-1}\right.$ ) in the $0-10 \mathrm{~cm}$ soil layer during Experiments 1 (a) and 2 (b). Vertical lines indicate standard errors.

between 34.3 and $36.2 \%$ with no significant differences between plots. Then, as occurred in experiment 1 , the addition of water enhanced soil moisture, reaching values of WFPS up to $49 \%$ in the two treatments with $14 \mathrm{~mm}$ of irrigation (i.e. $U+14$ and $\mathrm{U}+\mathrm{NBPT}+14)$. Measured soil temperature was slightly higher than in experiment 1 just after fertilising, at $15^{\circ} \mathrm{C}$, decreasing to $13.2{ }^{\circ} \mathrm{C}$ (i.e. 21st May).

\subsubsection{Evolution of mineral $N$ and urease activity}

There were no significant differences in urease activity between treatments immediately after fertilising. After $24 \mathrm{~h}$, similar to the first experiment, urease activity remained low for the treatments including NBPT. Without NBPT, urease activity increased over the first $24 \mathrm{~h}$. There was no apparent significant effect of irrigation with or without NBPT treatment groupings, with the exception of a greater initial increase in activity from $U+3+3$ compared with $U$ and $U+14$ (Fig. 1b).

An increase in soil $\mathrm{NH}_{4}^{+}$concentration was measured for all treatments $24 \mathrm{~h}$ after application, being significantly higher in $\mathrm{U}$ (Fig. 2b). Ammonium concentration in $U+14$ was significantly lower than that measured in the other two U fertilised soils throughout the experiment. Nevertheless, this concentration was still higher than that of the $\mathrm{U}+\mathrm{NBPT}$ fertilised plots $48 \mathrm{~h}$ after application, after which a progressive increase in $\mathrm{NH}_{4}^{+}$was measured in the $\mathrm{U}+\mathrm{NBPT}$ fertilised plots, with the exception of $U+N B P T+14$ soil where values remained below $100 \mathrm{mg} \mathrm{NH}_{4}^{+}-\mathrm{N} \mathrm{kg}^{-1}$. Contrarily, after the initial increase, there was a progressive decrease in the soil $\mathrm{NH}_{4}^{+}$content in
$\mathrm{U}$ until the end of the measurement period. An increase in soil $\mathrm{NH}_{4}^{+}$ concentration in $\mathrm{U}+3+3, \mathrm{NBPT}$ and $\mathrm{U}+\mathrm{NBPT}+3+3$ was measured 10 days after fertilising (i.e. 23rd of May), coinciding with the second simulated rainfall of $3 \mathrm{~mm}$. Finally, a general decrease in soil $\mathrm{NH}_{4}^{+}$was measured for all treatments from 23rd May until the end of the experiment (Fig. 2b).

The highest concentration of $\mathrm{NO}_{3}^{-}\left(41.3 \mathrm{mg} \mathrm{NO}_{3}^{-}-\mathrm{N} \mathrm{kg}^{-1}\right)$ in the upper soil was twice that of experiment 1 , being measured in $\mathrm{U}+1424 \mathrm{~h}$ after fertilising. Then, a decrease was measured in all treatments (Fig. $3 \mathrm{~b}$ ), in contrast to the previous experiment where the concentration grown at the end of the measurement period. Soil nitrate concentrations of $U+14$ and $U+N B P T+14$ were significantly higher than that of other treatments at the end of the sampling period.

\subsubsection{Ammonia emission}

Ammonia emission rate from $U$ peaked at $7 \mathrm{~d}$ after application, some days later than in Experiment 1 (Fig. 4). A similar pattern in emission rate and peak rate value was measured from $\mathrm{U}+3+3$ but with emission rates increasing and peaking $24 \mathrm{~h}$ sooner than for $\mathrm{U}$ (Fig. 4b).

Irrigation with $14 \mathrm{~mm}$ water significantly reduced emission rates, with a peak emission rate after $72 \mathrm{~h}$, much reduced compared with $U$ and $U+3+3$, after which emission rates were close to zero.

Inclusion of NBPT also significantly reduced emission rates, with rates from $U+$ NBPT and $U+$ NBPT +14 being close to zero throughout the experiment (Fig. 4b) and those from 

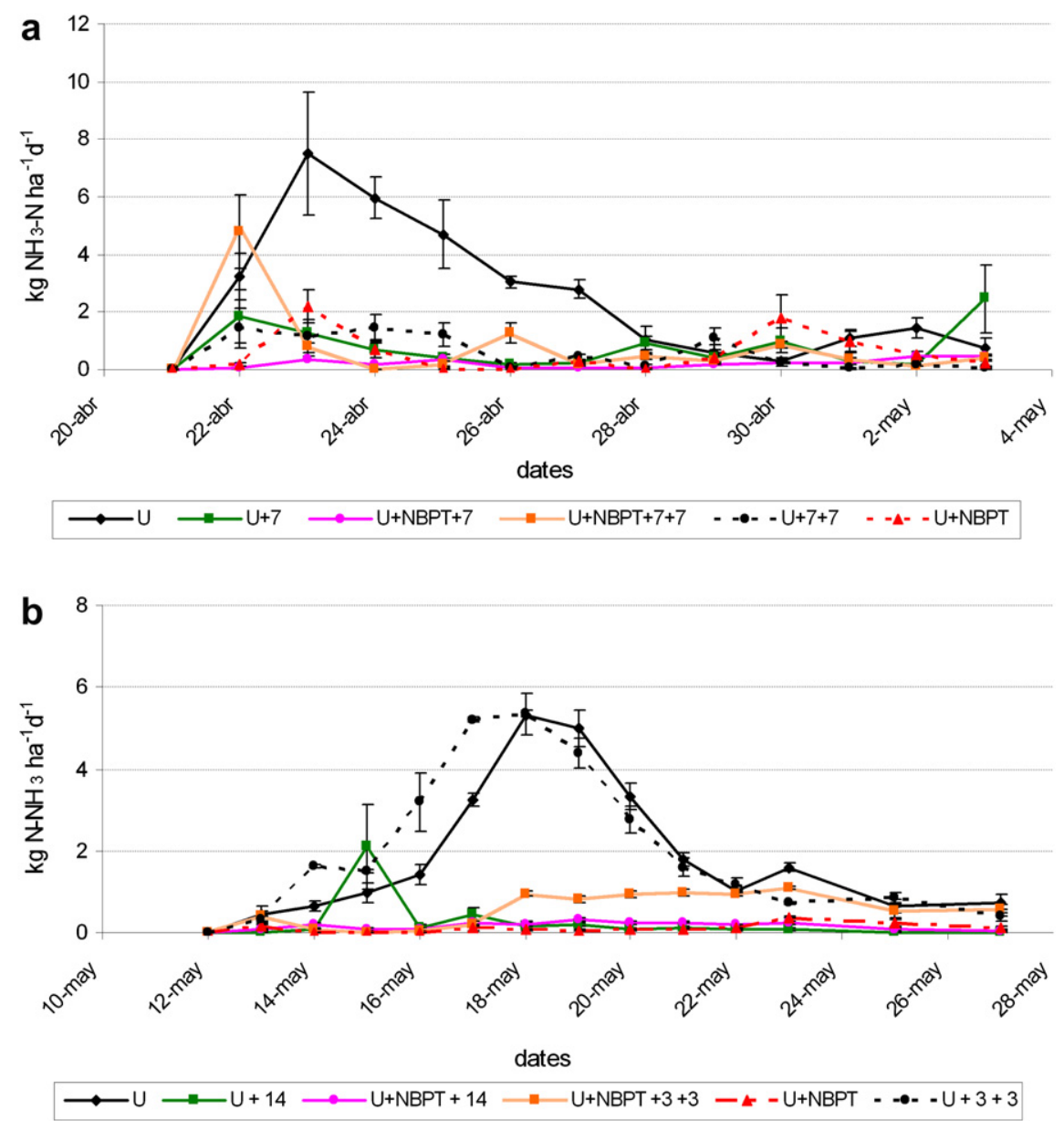

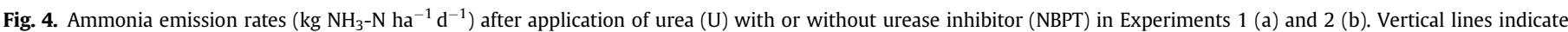
standard errors.

$\mathrm{U}+\mathrm{NBPT}+3+3$ initially close to zero but increasing to approximately $1 \mathrm{~kg} \mathrm{NH}_{3}-\mathrm{N} \mathrm{ha}^{-1} \mathrm{~d}^{-1}$ for the second week.

Cumulative emissions over $13 \mathrm{~d}$ were significantly greater from the $\mathrm{U}+3+3$ and $U$ than other treatments $\left(34.8 \pm 0.87 \mathrm{~kg} \mathrm{~N} \mathrm{ha}^{-1}\right.$ and $31.8 \pm 3.1 \mathrm{~kg} \mathrm{~N} \mathrm{ha}^{-1}$, a $76 \%$ and $69 \%$ of the $\mathrm{N}$ applied respectively), which were not significantly different between them (Table 1 ).

\section{Discussion}

\subsection{Effect of initial soil moisture and rainfall/irrigation} on $\mathrm{NH}_{3}$ emission abatement

Dissolution rate of surface applied urea could have been affected by the initial moisture content of soil. In this study, soil was always wet but the soil moisture prior to the application of treatments differed between the two experiments (averaging 62\% and 39\% for

Table 1

Cumulative $\mathrm{NH}_{3}-\mathrm{N}$ fluxes $\left(\mathrm{kg} \mathrm{NH}_{3}-\mathrm{N}^{-1}\right.$ ) during the experiment. Data are the averages of means from three replicates \pm standard deviation. Different letters within columns indicate significant differences by applying Fish Unprotected Least Significant Difference test at $P<0.05$.

\begin{tabular}{lrlr}
\hline Experiment 1 & \multicolumn{3}{c}{ Experiment 2} \\
\hline $\mathrm{U}$ & $31.4 \pm 5.8 \mathrm{~d}$ & $\mathrm{U}$ & $31.8 \pm 3.1 \mathrm{c}$ \\
$\mathrm{U}+\mathrm{NBPT}$ & $7.2 \pm 1.5 \mathrm{~b}$ & $\mathrm{U}+\mathrm{NBPT}$ & $3.5 \pm 1.0 \mathrm{a}$ \\
$\mathrm{U}+7$ & $7.1 \pm 2.1 \mathrm{~b}$ & $\mathrm{U}+14$ & $3.4 \pm 1.2 \mathrm{a}$ \\
$\mathrm{U}+\mathrm{NBPT}+7$ & $3.2 \pm 0.7 \mathrm{a}$ & $\mathrm{U}+\mathrm{NBPT}+14$ & $3.4 \pm 0.3 \mathrm{a}$ \\
$\mathrm{U}+7+7$ & $6.8 \pm 1.6 \mathrm{~b}$ & $\mathrm{U}+3+3$ & $34.8 \pm 0.9 \mathrm{c}$ \\
$\mathrm{U}+\mathrm{NBPT}+7+7$ & $11.9 \pm 0.9 \mathrm{c}$ & $\mathrm{U}+\mathrm{NBPT}+3+3$ & $13.0 \pm 2.4 \mathrm{~b}$ \\
\hline
\end{tabular}

experiments 1 and 2, respectively). These different conditions mainly affected the timing of the peak $\mathrm{NH}_{3}$ emission rate, being sooner in the wetter soil (the 2 nd and 7 th day for experiments 1 and 2, respectively). This may indicate that urea had been more rapidly dissolved in the upper part of the soil under the wettest conditions. Despite this difference, cumulative $\mathrm{NH}_{3}$ emissions from surface applied urea were not significantly different between the two experiments (Fig. 4). Therefore, the differences, in soil moisture and soil temperature, between these two experimental conditions were not a determining factor for $\mathrm{NH}_{3}$ volatilisation, and consequently a robust comparison of the different rainfall patterns evaluated was possible between the two experiments.

Cumulative $\mathrm{NH}_{3}$ emissions measured from the urea-only treatment in the present study were in the range of those reported elsewhere (e.g. Black et al., 1989; Ryden et al., 1987; Sommer and Jensen, 1994; Fox et al., 1996; Van der Weerden and Jarvis, 1997; Sanz-Cobena et al., 2008).

The addition of water (i.e. $\geq 7 \mathrm{~mm}$ ) immediately after surface urea application produced a significant reduction in $\mathrm{NH}_{3}$ emissions. This was probably because simulated rainfall, at rates of 7 and $14 \mathrm{~mm}$, would have distributed urea into the soil. Once in the soil, $\mathrm{NH}_{4}^{+}$ions, from urea hydrolysis, would have been subsequently immobilised on cation exchange sites, thus reducing the potential for volatilisation. Immediate water addition gave the main effect and there was little subsequent impact on $\mathrm{NH}_{3}$ emission of additional water application 1 week later, presumably because there would have been little urea remaining in the upper soil by this time. 
There was little difference in the emission reduction achieved between the $7 \mathrm{~mm}$ and $14 \mathrm{~mm}$ additions immediately following urea application (77\% and $89 \%$, respectively). However, a lower water addition rate (i.e. $3 \mathrm{~mm}$ ) gave no such abatement in emission, even enhancing them. Water addition would have accelerated urea dissolution and its hydrolysis, which would favour the formation of $\mathrm{NH}_{3}$ under the conditions of increasing $\mathrm{pH}$ associated with urea hydrolysis (Zaman et al., 2009), but the relatively low rate of added water would prevent the urea from being incorporated far into the soil matrix, thus only offering limited protection from volatilisation. This more rapid hydrolysis would explain the earlier increase in emission rate from $U+3+3$ compared with $U$ (Fig. 4 b). The results of the present study, although site-specific and influenced by the experimental conditions, would suggest that the UNECE suggested strategy of adding water (i.e. $10 \mathrm{~mm}$ ) following urea application (UNECE, 2001) is of the correct order, so that while promoting more rapid hydrolysis of the urea it will achieve sufficient incorporation of the dissolved urea into the soil matrix to provide a significant reduction in $\mathrm{NH}_{3}$ emission.

For drier soils (i.e. WFPS $\leq 20 \%$ ), it would be expected that a greater amount of water would be necessary in order to achieve an effective mitigation of $\mathrm{NH}_{3}$ volatilisation. However, the abating effect of adding water after urea fertilising under dry soil conditions may being more effective than for a saturated soil, where the infiltration rate of urea is expected to be low (Singh et al., 1984). This was the interpretation of Sanz-Cobena et al. (2008), who observed that irrigation with $10 \mathrm{~mm}$ immediately after urea fertilising of a dry semiarid soil (WFPS $\leq 20 \%$, bulk density of $1.57 \mathrm{~g} \mathrm{~cm}^{-3}$ ) resulted in a lower $\mathrm{NH}_{3}$ emission than expected, according to CORINAIR (2006), had there been no irrigation.

\subsection{Effect of NBPT on $\mathrm{NH}_{3}$ emission}

The inclusion of a urease inhibitor, NBPT, with urea application produced a mean reduction in $\mathrm{NH}_{3}$ emission of $77 \%$, similar to that reported by Dampney et al. (2004) in a tilled soil of the same experimental location (i.e. average reduction 65\%). This could be explained by the action of NBPT slowing urea hydrolysis through the inhibition of the urease enzyme in the soil and thus reducing the pool of exchangeable $\mathrm{NH}_{4}^{+}$. This allowed more time for urea to diffuse into the soil, lowering the amount of $\mathrm{NH}_{4}^{+}$in the upper soil $(0-5 \mathrm{~cm})$ susceptible to be transformed in $\mathrm{NH}_{3}$ and volatilised (Grant et al., 1996).

However, NBPT was not effective immediately after its application. The inhibitor did not affect urea hydrolysis within the first $24 \mathrm{~h}$ after fertilising, probably because an uncompleted oxidation to its active form, NBPTO (Manunza et al., 1999). Because of this, $\mathrm{NH}_{3}$ emission measured in the non-irrigated $U+$ NBPT treatment was not significantly different to that of the urea-only treatment immediately after fertilising (1st day). A significant effect of the inhibitor on the reduction of $\mathrm{NH}_{3}$ volatilisation was noticed $24 \mathrm{~h}$ after its application. This period was lower than that observed by Sanz-Cobena et al. (2008), who measured an "activation period" of 4 days in a semiarid tilled soil fertilised with urea.

The lower values of urease activity measured in the soil fertilised with $U+$ NBPT at that time (Fig. 1a), and the subsequent low $\mathrm{NH}_{3}$ volatilisation rates measured, would have been associated with the presence of NBPTO in most of the active sites of the enzyme. However, this effect was only maintained for 3 days.

The slowing effect of NBPT over urea hydrolysis, due to inhibited urease activity, affected the pool of mineral N. Ammonium content of the upper soil $(0-10 \mathrm{~cm})$ was lower than in the soil without the inhibitor, immediately after fertilising, followed by declining $\mathrm{NH}_{4}^{+}$ concentrations in all treatments. However, the decrease in the pool of $\mathrm{NH}_{4}^{+}$, mainly associated to the nitrification process, was lower with the inhibitor than in the soil fertilised with urea alone, probably due to a progressive loss of inhibition capacity of the inhibitor, which would have been associated with an increase in the urea hydrolysis. Importance of nitrification in the decrease of $\mathrm{NH}_{4}^{+}$ would have been confirmed by the high $\mathrm{NO}_{3}^{-}$concentration measured $24 \mathrm{~h}$ after fertilising in experiment 2 (Fig. 3b). In contrast, the $\mathrm{NO}_{3}^{-}$concentration in experiment 1 halved that of experiment 2 , probably due to both the urea and $\mathrm{N}$ leaching associated to the high soil water content measured.

\subsection{Combined effect of water management and NBPT on $\mathrm{NH}_{3}$ emission}

The combined effect on $\mathrm{NH}_{3}$ emission reduction of using the urease inhibitor NBPT and adding 7 or $14 \mathrm{~mm}$ of water to the soil immediately after application was not significantly different to that of the two strategies used separately (c. $80 \%$ reduction in both cases). Contrary to our initial hypothesis, that better distribution of NBPT in soil after water addition would enhance the effect, a similar rate of urea hydrolysis was measured for NBPT with water addition than for NBPT alone. This result would indicate that a correct irrigation management may produce a similar abatement effect to that associated with the use of the urease inhibitor NBPT, under the experimental conditions presented here. In contrast, application of an additional $3 \mathrm{~mm}$ of water 7 days after the application of $\mathrm{U}+\mathrm{NBPT}$ increased $\mathrm{NH}_{3}$ emission rate. This was probably because the second addition of water (i.e. $3 \mathrm{~mm}$ ) produced a reactivation of urea hydrolysis once the effectiveness of NBPTO ceased, which would have been responsible for the measured increase in the $\mathrm{NH}_{4}^{+}$ concentration and in the daily $\mathrm{NH}_{3}$ emission from the 6th day after fertilising until the end of the experimental period.

A second effect of combining both NBPT and water addition, when fertilising with urea, could be to reduce $\mathrm{NH}_{3}$ emissions during the so called "activation period". Application of water to the U + NBPT treated soil could have increased $\mathrm{NH}_{3}$ emission immediately after fertilising by promoting urea hydrolysis at a time when NBPT would not yet have been oxidised to NBPTO. However, the higher irrigation rate applied in the $U+N B P T+7$ and the $U+N B P T+14$ plots would have incorporated the fertiliser into the soil to such a depth that any $\mathrm{NH}_{3}$ produced would not have reached the exchange area between soil and air atmosphere (i.e. $0-5 \mathrm{~cm}$ depth).

We must be cautious in extrapolating the results from this study, pertaining to the specific soil and micrometereological conditions (e.g. soil $\mathrm{pH}$, temperature and moisture), to other conditions. However, from a qualitative perspective, these results can help to better understand those strategies that could be used in agricultural soils to mitigate $\mathrm{NH}_{3}$ from urea fertilised soils. Consequently, the use of NBPT by farmers could be limited when irrigation is commonly used. In semiarid countries, where irrigation is a management variable, the careful management of irrigation in relation to urea application could provide both economic and environmental benefits.

Finally, considering the measurement technique used, it is known that the wind tunnel method can bias results when compared to real conditions. Results from the few published studies in which comparisons have been made between measurement techniques, show that wind tunnels commonly give values of emission significantly higher than those estimated with micrometeorological techniques (e.g. Génermont et al., 1998; Loubet et al., 1999a,b; Smith et al., 2000; Misselbrook et al., 2005a,b). However, this methodology is very useful for comparative studies, as in the case of the present study in evaluating different strategies to mitigate $\mathrm{NH}_{3}$ emission.

\section{Conclusions}

The addition of water immediately after surface urea application can produce, depending on the rate and frequency of application, 
contrasting effects on $\mathrm{NH}_{3}$ volatilisation. In this study, $3 \mathrm{~mm}$ irrigation increased $\mathrm{NH}_{3}$ emissions by $8 \%$. However, 7 and $14 \mathrm{~mm}$ irrigation significantly reduced emissions (by 77 and 89\%, respectively), similar to the reduction in emissions achieved through the use of the urease inhibitor NBPT (77\%). Combined use of NBPT and water addition did not significantly increase the reduction efficiency. Targeted management of irrigation rate and timing following urea application to crops may therefore represent an alternative $\mathrm{NH}_{3}$ emission reduction strategy to the use of urease inhibitors in areas where irrigation is common management practice. Although the results of the present study have to be interpreted considering the specific soil conditions under which the experiments were carried out, they provide useful supporting evidence for the suggested UNECE strategy to mitigate $\mathrm{NH}_{3}$ emissions from urea application through immediate irrigation of $10 \mathrm{~mm}$ water.

\section{Acknowledgements}

The authors are grateful to the Spanish Minister of Science and Innovation for financing this research. It is a pleasure to acknowledge all the staff and researchers of North Wyke Research for their technical assistance. North Wyke is sponsored by the UK Biotechnology and Biological Sciences Research Council.

\section{References}

Black, A.S., Sherlock, R.R., Smith, N.P., Cameron, K.C., 1989. Ammonia volatilisation from urea broadcast in spring to autumn-sown wheat. New Zealand Journal of Crop and Horticultural Science 17, 175-182.

Bouwman, A.F., Lee, D.S., Asman, W.A.H., Dentener, F.J., Van der Hoek, K.W. Oliver, J.G.J., 1997. A global high-resolution emission inventory for ammonia. Global Biogeochemical Cycles 11, 561-587.

Carmona, G., Christianson, C.B., Byrnes, B.H., 1990. Temperature and low concentration effects of the urease inhibitor $\mathrm{N}$-(n-butyl) thiophosphoric triamide (NBPT) on ammonia volatilisation from urea. Soil Biology and Biochemistry 22, 933-937.

CORINAIR, 2006. http://reports.eea.europa.eu/EMEPCORINAIR4/en/B1010vs4.0.pdf.

Dampney, P.M.R., Chadwick, D., Smith, K.A., Bhogal, A., 2004. The behaviour of some different fertiliser-N materials. Report for Defra Project NT2603.

Danielson, R.E., Sutherland, P.L., 1986. Porosity. In: Klute, A. (Ed.), Methods of Soil Analysis, Part 1 - Physical and Mineralogical Methods. American Society of Agronomy, Madison, WI, pp. 443-460 (Chapter 18).

Erisman, J.W., Bleeker, A., Galloway, J., Sutton, M.S., 2007. Reduced nitrogen in ecology and the environment. Environmental Pollution 150, 140-149.

Findlay, D.C., Coleborne, G.J.N., Cope, D.W., Harrod, T.R., Hogan, D.V., Staines, S.J., 1984. Soils and their use in South West England. Soil Survey of England and Wales Bulletin no. 14. Harpenden, UK.

Fox, R.H., Piekielek, W.P., Macneal, K.E., 1996. Estimating ammonia volatilization losses from urea fertilisers using a simplified micrometeorological sampler. Soil Science Society of America Journal 60, 596-601.

Génermont, S., Cellier, P., Flura, D., Morvan, T., Laville, P., 1998. Measuring ammonia fluxes after slurry spreading under actual field conditions. Atmospheric Environment 32, 279-284.

Gill, J.S., Bijay-Singh, Khind, C.S., Yadvinder-Singh, 1997. Efficiency of N-(n-butyl) thiophosphoric triamide in retarding hydrolysis of urea and ammonia volatilization losses in a flooded sandy loam soil amended with organic materials. Nutrient Cycling in Agroecosystems 53, 203-207.

Grant, C.A., Jia, S., Brown, K.R., Bailey, L.D., 1996. Volatile losses of $\mathrm{NH}_{3}$ from surfaceapplied urea and urea ammonium nitrate with and without the urease inhibitors NBPT or ammonium thiosulphate. Canadian Journal of Soil Science 417-419.

Lockyer, D.R., 1984. A system for the measurement in the field of losses of ammonia through volatilization. Journal of the Science of Food and Agriculture 35 837-848.

Loubet, B., Cellier, S., Flura, D., Génermont, D., 1999a. An evaluation of the windtunnel technique for estimating ammonia volatilization from land: Part 1. Analysis and improvement of accuracy. 72, 71-81.

Loubet, B., Cellier, S., Génermont, D., Flura, D., 1999b. An evaluation of the windtunnel technique for estimating ammonia volatilization from land: Part 2. Influence of the tunnel on transfer processes. 72, 83-92.

Manugistics, 2000. Statgraphic Plus Version 5.1. Manugistics, Rockville, USA.

Manunza, B., Deiana, S., Pintore, M., Gessa, C., 1999. The binding mechanism of urea, hydroxamic acid and N-(N-butyl)-phosphoric triamide to the urease active site. A comparative molecular dynamics study. Soil Biology and Biochemistry 31, 789-796.

McCarty, G.W., Bremner, J.M., Chai, H.S., 1989. Effect of N-(n-butyl) thiophosphoric triamide on hydrolysis of urea by plant, microbial, and soil urease. Biology and Fertility of Soils 8, 123-127.

Misselbrook, T.H., Nicholson, F.A., Chambers, B.J., 2005a. Predicting ammonia loss following the application of livestock manure to land. Bioresource Technology 96, 159-168.

Misselbrook, T.H., Nicholson, F.A., Chambers, B.J., Johnson, R.A., 2005b. Measuring ammonia emissions from land applied manure: an intercomparison of commonly used samplers and techniques. Environmental Pollution 135, 389-397.

Nannipieri, P., Ceccanti, B., Cervelli, S., Matarese, E., 1980. Extraction of phosphatase, urease, proteases, organic carbon, and nitrogen from soil. Soil Science Society of America Journal 44, 1011-1016.

Ryden, J.C., Whitehead, D.C., Lockyer, D.R., Thompson, R.B., Skinner, J.H Garwood, E.A., 1987. Ammonia emission from grassland and livestock production systems in the UK. Environmental Pollution 48, 173-184.

Sanz-Cobena, A., Misselbrook, T.H., Arce, A., Mingot, J.I., Diez, J.A., Vallejo, A., 2008. An inhibitor of urease activity effectively reduces ammonia emissions from soil treated with urea under Mediterranean conditions. Agriculture, Ecosystems and Environment 126, 243-249.

Searle, P.L., 1984. The Berthelot or indophenol reaction and its use in the analytical chemistry of nitrogen: a review. The Analyst 109, 549-568.

Singh, M., Yadav, D.S., Kumar, V., 1984. Leaching and transformation of urea in dry and wet soils as affected by irrigation water. Plant and Soil 81, 411-420.

Smith, K.A., Jackson, D.R., Misselbrook, T.H., Pain, B.F., Johnson, R.A., 2000. Reduction of ammonia emission by slurry application techniques. Journal of Agricultural Engineering Research 77, 277-287.

Sommer, S.G., Jensen, C., 1994. Ammonia volatilisation from urea and ammoniacal fertilisers surface applied to winter wheat and grassland. Fertiliser Research 37, 85-92.

Sommer, S.G., Olesen, J.E., 1991. Effects of dry matter content and temperature on ammonia loss from surface-applied cattle slurry. Journal of Environmental Quality 20,679-683.

Thompson, R.B., Meisinger, J.J., 2004. Gaseous nitrogen losses and ammonia volatilization measurement following land application of cattle slurry in the midAtlantic region of the USA. Plant and Soil 266, 231-246.

UNECE, 2001. UNECE Framework Code for Good Agricultural Practices for Reducing Ammonia. Expert Group on Ammonia Abatement. United Nations Economic Commission for Europe, Geneva. http://www.clrtap-tfrn.org/sites/clrtaptfrn. org/files/documents/EPMAN\%20Documents/eb.air.wg.5.2001.7.e.pdf.

Van der Stelt, B., Temminghoff, E.J.M., Riemsdijk, W.H., 2005. Measurement on ion speciation in animal slurries using the Donnan membrane technique. Analytica Chimica Acta 552, 135-140.

Van der Weerden, T.J., Jarvis, S.C., 1997. Ammonia emission factors for N fertilizers applied to two contrasting grassland soils. Environmental Pollution 95, 205-211.

Van der Weerden, T.J., Moal, J.F., Martinez, J., Pain, B.F., Guiziou, F., 1996. Evaluation of the wind-tunnel method for measurement of ammonia volatilization from land. Journal of Agricultural Engineering Research 64, 11-13.

Zaman, M., Saggar, S., Blennerhassett, J.D., Singh, J., 2009. Effect of urease and nitrification inhibitors on $\mathrm{N}$ transformation, gaseous emissions of ammonia and nitrous oxide, pasture yield and $\mathrm{N}$ uptake in grazed pasture system. Soil Biology and Biochemistry 41, 1270-1280. 